\title{
EFFECT OF TRANSGENESIS ON QUALITY AND YIELD OF RABBIT MEAT
}

\author{
S. Dragin ${ }^{1}$, P. Chrenek ${ }^{2}$, B. Stančić ${ }^{1}$, A. Božići ${ }^{1}$ M. M. Petrović ${ }^{3}$ \\ ${ }^{1}$ Faculty of Agriculture, 21000, Novi Sad, Republic of Serbia \\ ${ }^{2}$ Research Institute of Animal Production, 949 92, Nitra, Slovakia \\ ${ }^{3}$ Institute for Animal Husbandry, 11080, Beograd-Zemun, Republic of Serbia \\ Corresponding author: saledragin@yahoo.com \\ Original scientific paper
}

\begin{abstract}
In this paper results of the effect of transgenesis on quality and yield of rabbit meat are presented. During the trial body mass of transgenic progeny of F1 generation was monitored and compared to control group (nontransgenic animals of same age). Subsequent to slaughtering, meat yield, ratio between certain musculature parts and meat quality (proteins, lipids, water) were analyzed. Obtained data was compared to control group of animals of same age but standard genotype. Meat colour was evaluated on apparatus Specol 11 and expressed as percentage of remission on wave length of $540 \mu \mathrm{m}$. Content of elements in thigh muscle was established subsequent to dry mineralization in spectro-photometer UNICAM 939 Cambridge UK. Phosphorus content was measured spectro-photometrically on apparatus SPECOL 11. Subsequent to measuring and systematization, data was statistically analyzed and processed. Arithmetic mean values for certain groups of data were calculated, and their values compared using t-test (Hadživuković, 1991). Changes established in regard to content of water, lipids, energy and water binding capacity, were relative to changes in histological structure and level of metabolic processes. It is possible that these changes are result of pleiotropic effect of integrated gene. However, in order to confirm and interpret these changes, it is necessary to carry out further researches of the microscopic structure and metabolic processes of muscle tissues in transgenic rabbits.
\end{abstract}

Key words: transgenesis, rabbit, meat, transgenic animals

\section{Introduction}

Progress of genetic engineering and biotechnology has enabled designing of transgenic organisms whose productive abilities are significantly greater and broader compared to those of the population of animals of standard genotypes (standard genotype is genotype not subjected to process of transgenesis). 
Transgenesis is procedure of creation of an individual of plant or animal species which in its genome possesses and transmits artificially introduced or altered gene, or gene group (transgene is sequence of genetic material isolated from the genome of single individual and transferred into genome of other individual of the same or different species). Based on fore mentioned facts, objective of this research was defined - to study meat traits of transgenic rabbits: meat yield, mutual ratio between certain muscle groups, meat quality (proteins, lipids, water) and compare them to control group of animals of standard genotype.

For practical application of transgenesis in animal production three aspects of this technology are primary: degree of integration of foreign gene into genome of manipulated embryo, phenotypic expression of altered genome in obtained animals and transmitting of altered genome on future generations. In this way it is possible to improve existing, but also produce new genetic traits in transgenic animals and their progeny (Pursel et al., 1990).

Previous research of the effect of transgenesis related to growth, carcass values and meat quality (Skrivanova et al., 2000; Ludewig et al., 2003) and according to results of mentioned authors it can in general be stated that these parameters have not demonstrated any impact by integrated WAP- hFVIII gene into rabbit genome. Water content in leg muscles of rabbits, according to results published in 1999 by Rafay et al. was $74,37 \pm 0,19 \%$. Szendro et al. (1996) reported results pertaining to water content of $73,8 \pm 0,044 \%$ in muscle samples from hind legs of rabbits weighing $2,5-2,59 \mathrm{~kg}$. Fat content influences the nutritive value of meat and its sensory traits. Szendro et al. (1996) presented mean value for fat content in leg muscles of $3,28 \pm 0,56 \%$.

Fat content increases to the detriment of water content as stated by numerous authors (Parigi- Bini et al., 1992; Bernardini Battaglini et al., 1994). It was established that in certain older rabbits the glycolysis increased, as well as myoglobine level and $\mathrm{pH}$ value decreased (Hulot and Ouhayoun, 1999; Dalle Zotte et al., 1996). Changes registered in regard to content of water, lipids, energy and water binding capacity are closely related to changes in the histological structure and level of metabolic processes.

\section{Materials and Methods}

Trial was carried out on commercial fattening hybrids created by crossing of New Zealand White and Californian rabbits. In the trial progeny of F1 generation of New Zealand White transgenic rabbits was used following the crossing of transgenic line founders (gene construction WAP- hFVIII) with non-transgenic rabbits of the same breed (Chrenek et al, 2003).

Animals were kept in wire cages in facilities with controlled environment/microclimate conditions. Air temperature in room was approx. 22 
$\pm 3^{\circ} \mathrm{C}$, relative air humidity $75 \pm 5 \%$ and animals had unrestricted access to food and water. Trial animals were fed balanced pelleted food. Rabbits were reared in the Research Institute of Animal Production, in Nitra, Slovak Republic.

During trial body mass of transgenic progeny of F1 generation was monitored and compared to control group (non-transgenic animals of same age). Subsequent to slaughtering of animals, meat yield was measured also mutual ratio between certain musculature parts and meat quality was analyzed (proteins, lipids, water). Obtained results were compared to control group of animals of same age and standard genotype.

Immediately after birth, tissue samples from ears were taken from new born animals and they were identified. Subsequently body mass of progeny was measured. Controls of body mass were carried out 1, 2, 5, 10, 20 and 30 days after birth, using digital laboratory weighing scale.

Following parameters were recorded in both animal groups: body mass (1, 2, $5,10,20$ and 30 days of age), slaughter data (w- weight prior to slaughtering, dwweight after bleeding, $\mathrm{s}$ - weight of skin, sp- weight of distal parts of hind legs, bweight of carcass side with skin, hd- weight of head without skin, fl- weight of fore legs, t- weight of thighs, r- weight of ribs (chest), bk - weight of back, ht- weight of heart, ky- weight of kidneys , l- weight of lungs, lv- weight of liver, git- weight of stomach and intestines including the intestinal content, f- weight of fat, btweight of leg bones, mt- weight of leg muscles, bf- weight of fore leg bones, cmeat yield (musculature \%)); thigh meat quality (cw- water content, $\mathrm{cp}$ - protein content, cf- fat content, ce- energy, $\mathrm{pH}$, cc- colour, bw- water binding capacity) and content of microelements in thigh meat $(\mathrm{Cu}, \mathrm{Zn}, \mathrm{Fe}, \mathrm{K}, \mathrm{Na}, \mathrm{Mg}, \mathrm{P}, \mathrm{Ca})$.

Thigh muscles (musculus biceps femoris) were used for chemical analysis of meat samples 1 hour subsequent to slaughtering. Muscle samples were wrapped in aluminium foil and stored at temperature of $4^{\circ} \mathrm{C}$ during 24 hours. $\mathrm{pH}$ value was determined using injection electrode and apparatus Radelkis OP- 10924 hours subsequent to slaughtering. Contents of water, proteins and intramuscular fat in muscle tissue were determined using Infratec 1265 apparatus 48 hours subsequent to slaughtering. Colour of meat was evaluated using apparatus Spekol 11 and expressed as percentage of remission at wave length of $540 \mu \mathrm{m}$. Content of elements in thigh muscle was determined after dry mineralization in spectrophotometer UNICAM 939 Cambridge UK. Phosphorus content was measured spectro-photometrically on apparatus SPECOL 11.

Subsequent to measuring and systematization, data was statistically analyzed and processed. Arithmetic mean values for certain groups of data were calculated, and their values compared using t-test (Hadživuković, 1991). In testing and evaluation of arithmetic means the following was compared:

- Arithmetic mean of samples with mean value of the main set from which the sample is originating, according to following formula: 
$t=\frac{\bar{x}-\mu}{S_{\bar{x}}}$, where: $\bar{x}$ - arithmetic mean of sample, $\mu$-arithmetic mean of the main set,

$S_{\bar{x}}$-standard error of arithmetic mean calculated from the sample

- Two arithmetic means of two independent samples, according to following formula:

$$
t=\frac{\bar{x}_{1}-\bar{x}_{2}}{S_{\left(\bar{x}_{1}-\bar{x}_{2}\right)}},
$$

where: $\bar{x}_{1}, \bar{x}_{2} \quad$ - arithmetic means of two independent samples, $S\left(\bar{x}_{1}-\bar{x}_{2}\right)$ - standard error of difference between arithmetic means calculated ffrom samples.

\section{Results and Discussion}

Low level of variability in all age categories in both observed groups was clearly visible from values of the standard error of arithmetic means. This was manifested by statistically significant effect of the transgenesis process on live weight at birth in spite of the fact that absolute difference of arithmetic means of transgenic and control group was only $0,005 \mathrm{~kg}(0,063 \pm 0,001$ vs. $0,058 \pm 0,002)$ (Table 1).

This effect was on threshold of $\mathrm{P}=0,05$ in table presenting variance analysis (Table 2). Difference between arithmetic means was not statistically significant in other age categories, and it disappeared after 48 hours. It can be concluded that the integrated gene had no effect on growth of transgenic rabbits.

Table 1. Statistical indicators of body mass $(\mathrm{kg})$ of rabbits

\begin{tabular}{|l|c|c|c|c|c|}
\hline \multirow{2}{*}{ Dan } & \multirow{2}{*}{$\mathrm{n}$} & Transgenic animals & \multirow{2}{*}{$\mathrm{n}$} & Control group & \multirow{2}{*}{ t-test } \\
& & $\bar{x} \pm \mathrm{S}_{\mathrm{x}}$ & & $\bar{x} \pm \mathrm{s}_{\mathrm{x}}$ & \\
\hline $1 \mathrm{~d}$ & 90 & $0,063 \pm 0,001$ & 45 & $0,058 \pm 0,002$ & + \\
\hline $2 \mathrm{~d}$ & 90 & $0,071 \pm 0,001$ & 45 & $0,068 \pm 0,002$ & - \\
\hline $5 \mathrm{~d}$ & 90 & $0,107 \pm 0,003$ & 42 & $0,108 \pm 0,004$ & - \\
\hline $10 \mathrm{~d}$ & 88 & $0,191 \pm 0,004$ & 42 & $0,187 \pm 0,006$ & - \\
\hline $20 \mathrm{~d}$ & 87 & $0,352 \pm 0,007$ & 42 & $0,347 \pm 0,010$ & - \\
\hline $30 \mathrm{~d}$ & 87 & $0,577 \pm 0,009$ & 42 & $0,584 \pm 0,013$ & - \\
\hline \multicolumn{2}{|r|}{$\mathrm{P} \geq 0,05^{*}$} \\
\hline
\end{tabular}


Table 2. Variance analysis of body mass of rabbits

\begin{tabular}{|c|c|c|c|c|c|c|}
\hline Age (days) & & $\begin{array}{l}\text { Animals with } \\
\text { integrated gene }\end{array}$ & SS & Control group & SS & $\mathrm{P}$ \\
\hline \multirow{2}{*}{$1 d$} & SK & 0,00065 & \multirow{2}{*}{1} & 0,00016 & \multirow{2}{*}{133} & \multirow{2}{*}{0,049} \\
\hline & F- test & $3,967^{+}$ & & & & \\
\hline \multirow{2}{*}{$2 \mathrm{~d}$} & SK & 0,00020 & \multirow{2}{*}{1} & 0,00016 & \multirow{2}{*}{133} & \multirow{2}{*}{0,274} \\
\hline & F- test & 1,207 & & & & \\
\hline \multirow{2}{*}{$5 \mathrm{~d}$} & SK & 0,00065 & \multirow{2}{*}{1} & 0,00060 & \multirow{2}{*}{130} & \multirow{2}{*}{0,992} \\
\hline & F- test & 0,00000 & & & & \\
\hline \multirow{2}{*}{$10 \mathrm{~d}$} & SK & 0,00040 & \multirow{2}{*}{1} & 0,00000 & \multirow{2}{*}{128} & \multirow{2}{*}{0,582} \\
\hline & F- test & 0,314 & & & & \\
\hline \multirow{2}{*}{$20 d$} & SK & 0,00072 & \multirow{2}{*}{1} & 0,00000 & \multirow{2}{*}{127} & \multirow{2}{*}{0,686} \\
\hline & F- test & 0,00002 & & & & \\
\hline \multirow{2}{*}{$30 \mathrm{~d}$} & SK & 0,00000 & \multirow{2}{*}{1} & 0,00000 & \multirow{2}{*}{127} & \multirow{2}{*}{0,660} \\
\hline & F- test & 0,200 & & & & \\
\hline
\end{tabular}

SK -square mean SS- freedom levels $\mathrm{P}$ - level of probability/likelihood $\mathrm{P} \geq 0,05^{+}$

Table 3. Main statistical characteristics of carcass quality (kg)

\begin{tabular}{|c|c|c|c|c|c|}
\hline \multirow[t]{2}{*}{ Carcass } & \multirow[t]{2}{*}{$\mathrm{n}$} & $\begin{array}{l}\text { Animals with } \\
\text { integrated gene }\end{array}$ & \multirow[t]{2}{*}{$\mathrm{n}$} & Control & \multirow[t]{2}{*}{$\mathrm{t}$ test } \\
\hline & & $\bar{x} \pm \mathrm{s}_{\mathrm{x}}$ & & $\bar{x} \pm \mathrm{s}_{\mathrm{x}}$ & \\
\hline $\mathrm{w}$ & 12 & $2,498 \pm 0,044$ & 15 & $2,576 \pm 0,039$ & - \\
\hline $\mathrm{dw}$ & 12 & $2,422 \pm 0,044$ & 15 & $2,497 \pm 0,0395$ & - \\
\hline $\mathrm{s}$ & 12 & $0,385 \pm 0,010$ & 15 & $0,390 \pm 0,009$ & - \\
\hline $\mathrm{sp}$ & 12 & $0,062 \pm 0,001$ & 15 & $0,069 \pm 0,001$ & + \\
\hline $\mathrm{b}$ & 12 & $1,355 \pm 0,056$ & 15 & $1,405 \pm 0,050$ & - \\
\hline hd & 12 & $0,119 \pm 0,003$ & 15 & $0,128 \pm 0,003$ & + \\
\hline $\mathrm{fl}$ & 12 & $0,199 \pm 0,004$ & 15 & $0,207 \pm 0,004$ & - \\
\hline$r$ & 12 & $0,298 \pm 0,008$ & 15 & $0,301 \pm 0,007$ & - \\
\hline bk & 12 & $0,266 \pm 0,008$ & 15 & $0,286 \pm 0,007$ & - \\
\hline $\mathrm{t}$ & 12 & $0,405 \pm 0,010$ & 15 & $0,433 \pm 0,009$ & + \\
\hline ht & 12 & $0,015 \pm 0,005$ & 15 & $0,017 \pm 0,005$ & - \\
\hline ky & 12 & $0,018 \pm 9,275$ & 15 & $0,019 \pm 8,296$ & - \\
\hline 1 & 12 & $0,020 \pm 0,002$ & 15 & $0,022 \pm 0,001$ & - \\
\hline lv & 12 & $0,079 \pm 0,004$ & 15 & $0,079 \pm 0,003$ & - \\
\hline git & 12 & $0,493 \pm 0,017$ & 15 & $0,520 \pm 0,015$ & - \\
\hline gite & 12 & $0,178 \pm 0,006$ & 15 & $0,189 \pm 0,005$ & - \\
\hline $\mathrm{f}$ & 12 & $0,023 \pm 0,014$ & 15 & $0,020 \pm 0,012$ & - \\
\hline $\mathrm{bt}$ & 12 & $0,065 \pm 0,006$ & 15 & $0,057 \pm 0,005$ & - \\
\hline $\mathrm{mt}$ & 12 & $0,264 \pm 0,024$ & 15 & $0,284 \pm 0,022$ & - \\
\hline bf & 12 & $0,051 \pm 0,010$ & 15 & $0,054 \pm 0,009$ & - \\
\hline $\mathrm{mf}$ & 12 & $0,134 \pm 0,010$ & 15 & $0,141 \pm 0,009$ & - \\
\hline c $(\%)$ & 12 & $60,448 \pm 1,882$ & 15 & $60,637 \pm 1,683$ & - \\
\hline
\end{tabular}

$\mathrm{P} \geq 0,05^{+}$ 
Statistical significance of the integrated gene was established in parameters which related to mass of distal parts of transgenic and non-transgenic rabbits $(0,062 \pm 0,001$ vs. $0,069 \pm 0,001 \mathrm{~kg})$, weight of head $(0,119 \pm 0,003$ vs. $0,128 \pm 0,003$ $\mathrm{kg})$ and thigh weight $(0,405 \pm 0,010$ vs. $0,433 \pm 0,009 \mathrm{~kg})$. In case of other tested slaughter characteristics no statistically significant differences induced by gene integration were established (Tables 3 and 4).

Table 4. Variance analysis of carcass quality

\begin{tabular}{|c|c|c|c|c|c|c|}
\hline Measures & & SS & $\begin{array}{c}\text { Animals with } \\
\text { integrated gene }\end{array}$ & SS & Control group & $\mathrm{P}$ \\
\hline \multirow{2}{*}{$\mathrm{w}$} & SK & \multirow{2}{*}{1} & 0,041 & \multirow{2}{*}{25} & 0,023 & \multirow{2}{*}{0,194} \\
\hline & F- test & & 1,781 & & & \\
\hline \multirow{2}{*}{ dw } & SK & \multirow{2}{*}{1} & 0,038 & \multirow{2}{*}{25} & 0,0234 & \multirow{2}{*}{0,218} \\
\hline & F- test & & 1,600 & & & \\
\hline \multirow[b]{2}{*}{$\mathrm{S}$} & SK & \multirow{2}{*}{1} & 1,666 & \multirow{2}{*}{25} & 0,001 & \multirow{2}{*}{0,722} \\
\hline & F- test & & 0,133 & & & \\
\hline \multirow{2}{*}{$\mathrm{sp}$} & SK & \multirow{2}{*}{1} & 2,963 & \multirow{2}{*}{25} & 2,389 & \multirow{2}{*}{0,002} \\
\hline & F- test & & $12,401^{+}$ & & & \\
\hline \multirow{2}{*}{ b } & SK & \multirow{2}{*}{1} & 0,045 & \multirow{2}{*}{25} & 0,037 & \multirow{2}{*}{0,285} \\
\hline & F- test & & 1,195 & & & \\
\hline \multirow{2}{*}{ hd } & SK & \multirow{2}{*}{1} & 5,281 & \multirow{2}{*}{25} & 1,044 & 0034 \\
\hline & F- test & & $5,057^{+}$ & & & 0,034 \\
\hline $\mathrm{fl}$ & SK & 1 & 4,126 & 25 & 2,063 & 0170 \\
\hline fl & F- test & 1 & 1,999 & 25 & & $0,1 / 0$ \\
\hline$r$ & SK & 1 & 6,000 & 25 & 7,800 & 0787 \\
\hline $\mathrm{r}$ & F- test & 1 & 0,077 & 25 & & $0, / 81$ \\
\hline bk & SK & & 0,003 & & 7,358 & \\
\hline bK & F- test & 1 & 3,552 & 25 & & $0,0 / 1$ \\
\hline t & SK & 1 & 0,005 & 25 & 0,001 & 0040 \\
\hline $\mathrm{t}$ & F- test & 1 & $4,277^{+}$ & 25 & & 0,049 \\
\hline ht & SK & 1 & 1,500 & 25 & 3,613 & 0847 \\
\hline nt & F- test & 1 & 0,042 & 25 & & 0,842 \\
\hline $\mathrm{ky}$ & SK & 1 & 1,245 & 25 & 1,032 & 0283 \\
\hline ку & F- test & 1 & 1,206 & 25 & & 0,283 \\
\hline 1 & SK & 1 & 1,965 & 25 & 3,179 & 0448 \\
\hline 1 & F- test & 1 & 0,618 & 25 & & 0,448 \\
\hline dy & SK & 1 & 1,896 & 25 & 1,549 & 0914 \\
\hline IV & F- test & 1 & 0,012 & 25 & & 0,914 \\
\hline oit & SK & 1 & 0,005 & 25 & 0,003 & 024 \\
\hline git & F- test & 1 & 1,444 & 25 & & 0,241 \\
\hline & SK & & 8,263 & & 4,194 & 0173 \\
\hline gite & F- test & 1 & 1,970 & 25 & & 0,173 \\
\hline$f$ & SK & 1 & 0,008 & 25 & 0,002 & 0084 \\
\hline 1 & F- test & 1 & 3,245 & 25 & & 0,084 \\
\hline ht & SK & 1 & 3,553 & 25 & 3,933 & 0361 \\
\hline $\mathrm{bt}$ & F- test & 1 & 0,903 & 25 & & 0,361 \\
\hline $\mathrm{mt}$ & SK & 1 & 0,003 & 25 & 0,007 & 0548 \\
\hline $\mathrm{mt}$ & F- test & 1 & 0,383 & 25 & & 0,548 \\
\hline hf & SK & 1 & 7,859 & 25 & 0,001 & 0795 \\
\hline bf & F- test & 1 & 0,071 & 25 & & 0,795 \\
\hline & SK & & 3,392 & & 0,001 & \\
\hline $\mathrm{mf}$ & F- test & 1 & 0,293 & 25 & & 0,599 \\
\hline . & SK & 1 & 4,879 & 25 & 42,504 & 0741 \\
\hline c & F- test & 1 & 0,115 & 25 & & 0,141 \\
\hline
\end{tabular}

SK - square mean; $\mathrm{SS}$ - freedom levels; $\mathrm{P} \geq 0,05^{+}$ 
On leg samples (thighs) values relating to meat quality were observed and studied (Tables 5 and 6). Obtained data which relate to meat composition (Table 5) indicated that the effect of gene integration was statistically significant $(p<0,05)$ in group of transgenic rabbits compared to non-transgenic animals in regard to following characteristics: protein content $(74,03 \pm 0,26$ vs. $74,84 \pm 0,28 \%)$, fat content $(3,66 \pm 0,40$ vs. $2,32 \pm 0,44 \%)$, energy content $(495,43 \pm 11,81$ vs. $458,07 \pm 12,94 \%)$ and water binding capacity $(31,66 \pm 0,84$ vs. $35,63 \pm 0,92 \%)$.

Statistically significant differences as consequence of the effect of the integrated gene were not determined in other observed parameters (Table 6).

Table 5. Main statistical parameters of the chemical composition of rabbits' meat (transgenic and control animals)

\begin{tabular}{|c|c|c|c|c|c|}
\hline \multirow[t]{2}{*}{ Parameter } & \multirow{2}{*}{$\mathrm{n}$} & $\begin{array}{l}\text { Animals with integrated } \\
\text { gene }\end{array}$ & \multirow{2}{*}{$\mathrm{n}$} & Control group & \multirow{2}{*}{ t-test } \\
\hline & & $\bar{x} \pm \mathrm{s}_{\mathrm{x}}$ & & $\bar{x} \pm \mathrm{s}_{\mathrm{x}}$ & \\
\hline $\mathrm{cw}(\%)$ & 12 & $74,03 \pm 0,26$ & 10 & $74,84 \pm 0,28$ & + \\
\hline cp $(\%)$ & 12 & $21,45 \pm 0,26$ & 10 & $22,12 \pm 0,29$ & - \\
\hline $\operatorname{cf}(\%)$ & 12 & $3,67 \pm 0,40$ & 10 & $2,32 \pm 0,44$ & + \\
\hline ce $(\mathrm{kJ})$ & 12 & $495,43 \pm 11,81$ & 10 & $458,07 \pm 12,94$ & - \\
\hline $\mathrm{pH}$ & 12 & $5,79 \pm 0,10$ & 10 & $5,48 \pm 0,11$ & - \\
\hline cc $(\%)$ & 10 & $20,94 \pm 1,58$ & 10 & $25,44 \pm 1,58$ & - \\
\hline bw (\%) & 12 & $31,66 \pm 0,84$ & 10 & $35,63 \pm 0,92$ & + \\
\hline
\end{tabular}

$$
\mathrm{P} \geq 0,05^{+}
$$

Mean values of element content in muscle tissue showed the greatest variations of all observed parameters. The most expressive variations were in the group of non-transgenic rabbits (Table 7). Number of animals or repetitions played significant role.

Values obtained during trial which related to growth, carcass/slaughter value and meat quality were fully in accordance to results stated by Skrivanova et al., (2000) and Ludewig et al. (2003).

For most of the observed characteristics it can be stated that no significant effect of integrated WAP- hFVIII gene in rabbit genotype was demonstrated. More 
significant differences occurred only within some parameters of the meat quality (Table 8). It should be pointed out that also the presence of rhFVIII in skeletal muscles of transgenic rabbits was not established.

Table 6. Variance analysis of chemical composition of rabbits' meat

\begin{tabular}{|c|c|c|c|c|c|c|}
\hline Parameter & & SS & $\begin{array}{l}\text { Animals with } \\
\text { integrated gene }\end{array}$ & SS & Control group & $\mathrm{P}$ \\
\hline \multirow[b]{2}{*}{$\mathrm{cw}$} & SK & \multirow[b]{2}{*}{1} & 3,623 & \multirow{2}{*}{20} & 0,802 & \multirow{2}{*}{0,046} \\
\hline & F- test & & $4,516^{+}$ & & & \\
\hline \multirow{2}{*}{$\mathrm{cp}$} & SK & \multirow{2}{*}{1} & 2,522 & \multirow{2}{*}{20} & 0,840 & \multirow{2}{*}{0,098} \\
\hline & F- test & & 3,004 & & & \\
\hline \multirow{2}{*}{$\mathrm{cf}$} & SK & \multirow{2}{*}{1} & 9,892 & \multirow{2}{*}{20} & 1,904 & \multirow{2}{*}{0,034} \\
\hline & F- test & & $5,195^{+}$ & & & \\
\hline \multirow{2}{*}{ ce } & SK & \multirow{2}{*}{1} & 7613,696 & \multirow{2}{*}{20} & 1673,187 & \multirow{2}{*}{0,046} \\
\hline & F- test & & 4,550 & & & \\
\hline \multirow{2}{*}{$\mathrm{pH}$} & SK & \multirow{2}{*}{1} & 0,529 & \multirow{2}{*}{20} & 0,128 & \multirow{2}{*}{0,055} \\
\hline & F- test & & 4,131 & & & \\
\hline \multirow{2}{*}{$\mathrm{cc}$} & SK & \multirow{2}{*}{1} & 101,250 & \multirow{2}{*}{18} & 24,949 & \multirow{2}{*}{0,059} \\
\hline & F- test & & 4,058 & & & \\
\hline \multirow{2}{*}{ bw } & SK & \multirow{2}{*}{1} & 86,019 & \multirow{2}{*}{20} & 8,556 & \multirow{2}{*}{0,005} \\
\hline & F- test & & $10,054^{+}$ & & & \\
\hline
\end{tabular}

$\mathrm{SK}$ - square mean, $\mathrm{SS}$ - freedom levels , $\mathrm{P} \geq 0,05^{+}$

Table 7. Main statistical characteristics of the content of chemical elements in the rabbits' meat (transgenic and control animals)

\begin{tabular}{|c|c|c|c|c|c|}
\hline \multirow{2}{*}{$\begin{array}{l}\text { Element } \\
\text { (unit of measure) }\end{array}$} & \multirow{2}{*}{$\mathrm{n}$} & $\begin{array}{l}\text { Animals with } \\
\text { integrated gene }\end{array}$ & \multirow{2}{*}{$\mathrm{n}$} & Control group & \multirow{2}{*}{ t-test } \\
\hline & & $\bar{x} \pm \mathrm{s}_{\mathrm{x}}$ & & $\bar{x} \pm \mathrm{s}_{\mathrm{x}}$ & \\
\hline $\mathrm{Cu}(\mathrm{mg} / \mathrm{kg})$ & 12 & $1,15 \pm 0,21$ & 10 & $0,86 \pm 0,23$ & - \\
\hline $\mathrm{Zn}(\mathrm{mg} / \mathrm{kg})$ & 12 & $17,23 \pm 4,43$ & 10 & $18,23 \pm 4,85$ & - \\
\hline $\mathrm{Fe}(\mathrm{mg} / \mathrm{kg})$ & 12 & $17,14 \pm 6,02$ & 10 & $20,99 \pm 6,60$ & - \\
\hline $\mathrm{K}(\mathrm{g} / \mathrm{kg})$ & 12 & $5,17 \pm 0,32$ & 10 & $5,44 \pm 0,35$ & - \\
\hline $\mathrm{Na}(\mathrm{g} / \mathrm{kg})$ & 12 & $0,80 \pm 0,08$ & 10 & $0,77 \pm 0,09$ & - \\
\hline $\operatorname{Mg}(\mathrm{g} / \mathrm{kg})$ & 12 & $0,40 \pm 0,06$ & 10 & $0,44 \pm 0,07$ & - \\
\hline$P(g / k g)$ & 12 & $2,30 \pm 0,37$ & 10 & $2,93 \pm 0,40$ & - \\
\hline $\mathrm{Ca}(\mathrm{g} / \mathrm{kg})$ & 12 & $0,30 \pm 0,05$ & 10 & $0,23 \pm 0,06$ & - \\
\hline
\end{tabular}


Variance analysis (Table 8) showed absence of statistical significance of the effect of gene integration for all observed elements.

Table 8. Variance analysis of content of chemical elements in rabbits' meat

\begin{tabular}{|c|c|c|c|c|c|c|}
\hline Element & & SS & $\begin{array}{l}\text { Animals with integrated } \\
\text { gene }\end{array}$ & SS & Control group & $\mathrm{P}$ \\
\hline \multirow{2}{*}{$\mathrm{Cu}$} & SK & \multirow{2}{*}{1} & 0,455 & \multirow{2}{*}{20} & 0,552 & \multirow{2}{*}{0,384} \\
\hline & F- test & & 0,824 & & & \\
\hline \multirow{2}{*}{$\mathrm{Zn}$} & SK & \multirow{2}{*}{1} & 5,371 & \multirow{2}{*}{20} & 235,652 & \multirow{2}{*}{0,883} \\
\hline & F- test & & 0,023 & & & \\
\hline \multirow{2}{*}{$\mathrm{Fe}$} & SK & \multirow{2}{*}{1} & 80,954 & \multirow{2}{*}{20} & 435,320 & \multirow{2}{*}{0,676} \\
\hline & F- test & & 0,186 & & & \\
\hline \multirow{2}{*}{ K } & SK & \multirow{2}{*}{1} & 0,382 & \multirow{2}{*}{20} & 1,227 & \multirow{2}{*}{0,589} \\
\hline & F- test & & 0,311 & & & \\
\hline \multirow{2}{*}{$\mathrm{Na}$} & SK & \multirow{2}{*}{1} & 0,004 & \multirow{2}{*}{20} & 0,080 & \multirow{2}{*}{0,823} \\
\hline & F- test & & 0,053 & & & \\
\hline \multirow{2}{*}{$\mathrm{Mg}$} & SK & \multirow{2}{*}{1} & 0,008 & \multirow{2}{*}{20} & 0,044 & \multirow{2}{*}{0,672} \\
\hline & F- test & & 0,190 & & & \\
\hline \multirow{2}{*}{$\mathrm{P}$} & SK & \multirow{2}{*}{1} & 2,166 & \multirow{2}{*}{20} & 1,614 & \multirow{2}{*}{0,260} \\
\hline & F- test & & 1,342 & & & \\
\hline \multirow{2}{*}{$\mathrm{Ca}$} & SK & \multirow{2}{*}{1} & 0,027 & \multirow{2}{*}{20} & 0,035 & \multirow{2}{*}{0,398} \\
\hline & F- test & & 0,776 & & & \\
\hline
\end{tabular}

$\mathrm{SK}$ - square mean, SS - freedom levels, $\mathrm{P} \geq 0,05^{+}$

Water content in leg muscles of rabbits from both studied groups was in

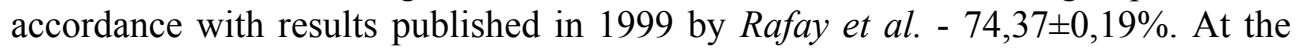
same time Szendro et al. (1996) reported result of $73,8 \pm 0,044 \%$ of water content in samples from hind leg muscles of rabbits weighing $2,5-2,59 \mathrm{~kg}$. Statistically significant difference in water content in leg muscles determined in our researches between transgenic and non-transgenic animals was 0,81\%. This difference can be explained by sample manipulation prior to analysis as well as low level of variability of statistical group.

Musculature fat is in form of phospholipids as constituents of muscle contractile fibres, fibroblast and adipocyte membranes, as well as glycerides 
located on adipocytes surrounding the fibres and free fatty acids. Fat is influencing the nutritive value of meat and its sensory traits.

Szendro et al. (1996) stated mean value of fat/lipid content in leg muscles of $3,28 \pm 0,56 \%$. Our results showed that in transgenic animals content of fat/lipids in leg muscles was $3,67 \pm 0,40 \%$. According to Lambertini et al. (1996) and Hernandezu et al. (1998) differences in parameters determining the quality of meat in rabbits are constant. In general, improvement of qualitative meat parameters is associated with intensifying of the body growth. Content of fat/lipids increases to the detriment of water content (Parigi- Bini et al., 1992; Bernardini Battaglini et al., 1994). It was established that in certain older rabbits the glycolysis increased, as well as myoglobine level and $\mathrm{pH}$ value decreased (Hulot and Ouhayoun, 1999; Dalle Zotte et al., 1996). Changes established in regard to content of water, lipids, energy and water binding capacity, were relative to changes in histological structure and level of metabolic processes. It is possible that these changes are result of pleiotropic effect of integrated gene. However, in order to confirm and interpret these changes, it is necessary to carry out further researches of the microscopic structure and metabolic processes of muscle tissues in transgenic rabbits.

\section{Conclusion}

Transgenic animals offer invaluable amount of information for better understanding of the mechanisms of the functioning of mammal organism. However, after twenty year research, use of transgenesis in animal production is still limited compared to plant production. This is mainly due to technical problems, insufficient knowledge of the gene map of mammals, instability of integrated genes, as well as high cost of creation of transgenic populations. Objective success in animal transgenesis is for now in researches of fundamental character, such as determination of the function of DNA segments and genome mapping. Based on presented results of the research the following can be concluded:

- Observed values pertaining to meat yield showed no statistically significant difference except greater body mass at birth of rabbit progeny deriving from transgenic females;

- In case of some slaughter values significant difference was registered: in transgenic rabbits greater weight of head was observed, also of carcasses and somewhat higher ratio of weights of distal carcass parts;

- The influence of gene integration was demonstrated on protein content of meat (higher in non-transgenic rabbits), content of fat/lipids in meat (higher in transgenic rabbits) which induced higher energy content and water binding capacity (higher in non-transgenic rabbits, in inverse proportion to fat content). 


\title{
Uticaj transgenaze na kvalitet i prinos mesa kunića
}

\author{
S. Dragin, P. Chrenek, B. Stančić, A. Božić, M. M. Petrović
}

\section{Rezime}

U radu su prikazani rezultati uticaja transgeneze na kvalitet i prinos mesa kunića. Ogled je vršen na komercijalnim tovnim hibridima nastalim ukrštanjem Novozelandskih belih i Kalifornijskih kunića. Dobijeni podaci upoređeni su sa kontrolnom grupom vršnjaka standardnog genotipa. Posmatrani su sledeći parametri kod obe grupe životinja: telesna masa $(1,2,5,10,20$ i 30- tog dana starosti), klanični podaci (w- težina pre žrtvovanja, dw- težina nakon iskrvarenja, $s$ - težina kože, sp- težina distalnih delova zadnjih nogu, b- težina polutke sa kožom, hd- težina glave bez kože, fl- težina prednjih nogu, t- težina butova, r- težina rebara (grudi), bk - težina leđa, ht- težina srca, ky- težina bubrega, 1- težina pluća, lvtežina jetre, git- težina stomaka i creva sa sadržajem, gite- težina praznog stomaka i creva, f- težina masnoće, bt- težina kostiju nogu, mt- težina mišića nogu, bf- težina kostiju prednjih nogu, c- prinos mesa (obraslost muskulaturom \%); kvalitet mesa butova (cw- sadržaj vode, $\mathrm{cp}$ - sadržaj proteina, cf- sadržaj masti, ce- energija, $\mathrm{pH}$, cc- boja, bw- kapacitet zadržavanja vode) i sadržaj mikroelemenata u mesu buta $(\mathrm{Cu}, \mathrm{Zn}, \mathrm{Fe}, \mathrm{K}, \mathrm{Na}, \mathrm{Mg}, \mathrm{P}, \mathrm{Ca})$.

Posle merenja i sistematizacije podaci su statistički obrađeni. Izvršena su izračunavanja aritmetičkih sredina pojedinih grupa podataka, a zatim poređenje njihovih vrednosti t-testom (Hadživuković, 1991).

Nizak nivo varijabiliteta $\mathrm{u}$ svim starosnim kategorijama $\mathrm{u}$ obe posmatrane grupe je jasno vidljiv iz vrednosti standardne greške aritmetičke sredine. To je manifestovano statistički značajnim uticajem procesa transgeneze na živu masu pri rođenju uprkos činjenici da je apsolutna razlika aritmetičkih sredina transgene i kontrolne grupe samo $0,005 \mathrm{~kg}(0,063 \pm 0,001$ nasuprot $0,058 \pm 0,002)$ (tabela 1).

Ovaj uticaj je na granici $\mathrm{P}=0,05$ u tabeli analize varijanse (tabela 2). Razlika aritmetičkih sredina nije statistički značajna kod ostalih starosnih kategorija i ona se gubi već nakon 48 časova. Može se konstatovati da integrisani gen nema uticaja na porast transgenih kunića.

Statistički značaj uticaja integrisanog gena je utvrđen kod parametara koji se odnose na masu distalnih delova transgenih i netransgenih kunića $(0,062 \pm 0,001$ nasuprot $0,069 \pm 0,001 \mathrm{~kg})$, težine glave $(0,119 \pm 0,003$ nasuprot $0,128 \pm 0,003 \mathrm{~kg}) \mathrm{i}$ težine butova $(0,405 \pm 0,010$ nasuprot $0,433 \pm 0,009 \mathrm{~kg})$. Kod ostalih klaničnih karakteristika koje su testirane nisu utvrđene statistički značajne razlike koje bi bile uslovljene integracijom gena (tabele 3 i 4 ). 
$\mathrm{Na}$ uzorcima mesa nogu (butovi) praćene su vrednosti koje se odnose na kvalitet mesa (tabele 5 i 6). Dobijeni podaci koji se odnose na sastav mesa (tabela 5) ukazuju da je uticaj integracije gena bio statistički značajan $(p<0,05)$ u grupi transgenih kunića u poređenju sa netransgenim u pogledu sledećih karakteristika: sadržaj proteina $(74,03 \pm 0,26$ nasuprot $74,84 \pm 0,28 \%)$, sadržaj masnoće $(3,66 \pm 0,40$ nasuprot $2,32 \pm 0,44 \%)$, sadržaja energije $(495,43 \pm 11,81$ nasuprot $458,07 \pm 12,94 \%$ ), kapacitet zadržavanja vode $(31,66 \pm 0,84$ nasuprot $35,63 \pm 0,92 \%)$.

Statistički značajne razlike kao posledica uticaja integrisanog gena nisu utvrđene kod ostalih posmatranih parametara (tabela 6).

Srednje vrednosti sadržaja elemenata u tkivu mišića pokazale su najveće varijacije od svih posmatranih parametara. Najizraženije varijacije bile su u grupi netransgenih kunića (tabela 7). Broj životinja ili ponavljanja je igrao veliku ulogu.

Za većinu posmatranih karakteristika može se reći da nisu pokazale uticaj integrisanog WAP- hFVIII gena u genotipu kunića. Značajnije razlike pojavile su se samo u okviru nekih parametara kvaliteta mesa (tabela 8). Rezultati ukazuju da nije utvrđeno ni prisustvo rhFVIII u skeletnim mišićima transgenih kunića.

\section{References}

BERNARDINI BATTAGLINI M., CASTELLINI C., LATTAIOLI P.(1994) : Rabbit carcass and meat quality: effect of strain, rabittry and age. Ital. J. Food Sci., 2, 157-166.

CHRENEK P., VASICEK D., MAKAREVICH A., JURCIK R., SUVEGOVA K., BAUER M., RAFAY J. BULLA J., HETENYI L., ERICKSON J. AND PALEYANDA R. K.(2003): Integration rates of exogenous DNA into the rabbit genome using single and double pronuclei microinjection. Transgenic Animal Research Conference IV, 101.

DALLE ZOTTE A., OUHAYOUN J., PARIGI BINI R., XICCATO G. (1996): Effect of age, diet and sex on muscle energy metabolism and on related physicochemical traits in the rabbits. Meat Sci., 43, 15-24.

DRAGIN S. (2003): Proizvodnja i osobine transgenih kunića. Magistarska teza, Poljoprivredni fakultet, Novi Sad.

DRAGIN S., BOZIC A., CHRENEK P.(2004): Effect of Transgenesis on F2 and F3 rabbit offspring generation. 5th. scientific conference of $\mathrm{PhD}$. students, University of Constantine Philosophie, Nitra, Slovakia, 28-32.

HADŽIVUKOVIĆ S. (1991): Statistički metodi s primenom u poljoprivrednim i biološkim istraživanjima. Institut za ekonomiku poljoprivrede i sociologiju sela, Poljoprivredni fakultet, Univerzitet u Novom Sadu.

HERNÁNDEZ P., PLA M, BLASCO A. (1998): Carcass characteristics and meat quality of rabbit lines selected for different objectives: II. Relationships between meat characteristics. Livestock Prod. Sci., 54, 115-123. 
HULOT F., OUHAYOUN J.(1999): Muscular $\mathrm{pH}$ and related traits in rabbits: a review. World Rabbit Sci., 7, 15-36.

LAMBERTINI L., BERGOGLIO G., MASOERO G., GRAMENZI A.(1996): Comparison between Provisal and Hyla rabbit strains. I. Slaughtering performances and muscle composition. Proc. 6th WRSA Congress, 3, 195-199.

LUDEWIG M., TREEL VAN N., FEHLHABER K.(2003): Schlachtausbeute und Fleischqualität von Mastkaninchen in Abhängigkeit vom Alter. Fleischwirtschaft, 101-103.

PARRIGI-BINI R., ZICCATO G., CINETTO M., DALLE ZOTTE A.(1992): Effetto dell'età e peso di macellazione e del sesso sulla qualità della carcassa e della carne cunicola.2. Composizione chimica e qualità della carne. Zoot. Nutr. Anim., 18, 173-190.

PURSEL V.G., BOLT J.D., MILLER F.K., PINKERT A.C., HAMMERT E.R., PALMITER D.R., BRINSTER L.R. (1990): Expression and performance in transgenic pigs. J. Reprod. Fert., Suppl., 40, 42-55.

RAFAY J., MOJTO J., PALANSKÁ O. (1999): Characteristics of meat quality of domestic rabbit. Pol'nohospodárstvo (Agriculture), 45, 388-396.

SKŘIVANOVÁ V., MAROUNEK M., TƯMOVÁ E., SKŘIVAN M., LAŠTOVKOVÁ J. (2000): Performance, carcass yield and quality of meat in broiler rabbits: a comparison of six genotypes. Czech J. Anim. Sci., 45, 91- 95.

SZENDRÖ Z.S., RADNAI I., BIRÓ-NÉMETH E., ROMVÁRI R., MILISITS G.(1996): Changes in water, protein, fat and ash content in the meat of rabbits between $2.2-3.5 \mathrm{~kg}$ live weight. Proc. 6th WRSA Congress, 3, 269-272 